\title{
Troublesome trade-offs: balancing urban activities and values when securing a city-centre governmental quarter
}

\author{
Sunniva F Meyer ${ }^{1 *}$, Sissel H Jore ${ }^{2}$ and Kjell W Johansen ${ }^{3}$
}

\begin{abstract}
Background: Homeland security measures increasingly affect urban life and activities. Standoff distance, which prevents unscreened vehicles from approaching within a certain distance of a building, is a widely applied measure when protecting buildings against attacks with vehicle-borne improvised explosive devices. This measure both is rather inexpensive and has few negative externalities when implemented in rural areas. Unfortunately, sites with protection needs often are situated in city centres.
\end{abstract}

Methods: We apply the so-called Security Function Framework to illuminate the externalities or the 'troublesome trade-offs' between protecting a high-value site against vehicle-borne improvised explosive devices and protecting other urban values.

Results: This paper demonstrates that standoff creates challenges for other important values, such as functional office spaces for all employees, deliveries and emergency vehicle access. Simultaneously, standoff creates opportunities for reinforcing social-responsibility requirements, such as accessibility for pedestrians and environmental considerations.

Conclusions: Security measures can have both negative and positive externalities and planning might alleviate some of the negative ones.

Keywords: External effects; Design conflicts; Contradictions; Security; Vehicle-borne improvised explosive devices; Standoff distance measures; City centres; Holistic security

\section{Background}

On 22 July 2011 at 3:17 pm Anders Behring Breivik left a vehicle-borne explosive device in the government complex of Norway. The bomb detonated at 3:25 pm, killing eight people and destroying three government buildings (The Public Prosecutors 2012). A reduced presence of government employees (it was late Friday afternoon and the holiday season), together with the fact that no building collapsed, limited causalities. The amount of damage did, however, induce the government to examine the possibility of redeveloping the government complex to enable the majority of the ministries to move into it in future (Ministry of Local Government and Modernisation 2013).

Following the bomb attack on the government complex, the focus on measures that protect against vehicle-borne

\footnotetext{
* Correspondence: sfm@toi.no

'Department of Safety, Security and the Environment, Institute of Transport Economics, Gaustadalleen 21, NO-0349 Oslo, Norway

Full list of author information is available at the end of the article
}

improvised explosive devices (VBIED) has increased drastically, both when protecting the current buildings and when planning the future government complex (FGC). Current practice for protecting buildings against such attacks is to combine measures that strengthen the building and its facade with a standoff around the building (Ettouney et al. 1996). Since the effect of a bomb decreases exponentially with distance from the bomb, a standoff that creates distance between a potential explosive and a building is a very effective measure (Cormie et al. 2009; Gebbeken et al. 2012).

Creating standoff in rural areas where land is cheap and available is relatively inexpensive and easy. Unfortunately, many buildings with protection needs are situated in city centres where land is expensive and annexation of land can have major disadvantages for the building's users, its neighbours, and other members of the public. The purpose of this paper is to identify and explain the various 
trade-offs between standoff and other values, and, where appropriate, to propose possible solutions to such dilemmas. We do all three by employing the "The Security Function Framework' (SFF), as formulated in Ekblom (2012), in the case of the FGC of Norway. The FGC of Norway is an example of a multifaceted project that requires protective security while being situated in a city centre where land is scarce.

Ekblom (2005) introduces the term 'troublesome tradeoffs' when describing the potentially conflicting requirements which must be considered by the designer. Conflicting requirements include values such as aesthetics, legal and ethical issues, environmental considerations, safety, convenience, cost, and social inclusion (Ekblom 2005,2012 ). The pursuit of security involves handling many such troublesome trade-offs, including that security may suspend normal democratic freedom in zones of high security and that security dictates that we should distrust others (Zedner 2003). CCTV, for example, can encourage social inclusion by increasing perceived safety (LoukaitouSideris 2006), while also facilitating discriminatory practices and can thus cause social exclusion (Sætnan et al. 2002). Security may even replace public spaces with private spaces, such as the case of gated communities. Paradoxically, such private security may reduce public order by removing the responsibility of the inhabitants for the "outside" (Lemanski 2004).

Gebbeken et al. 2012 argue that since a free democratic society will never accept a surveillance state, we need passive security measures, such as innovative and architecturally attractive buildings and landscape elements. Such measures, however, also entail troublesome trade-offs. Khajehpour and Grierson (2003) demonstrate that high-rise office buildings 'designs with the most profit potential and those with the most safety potential correspond to buildings that also are the least safe and the least profitable, respectively' (Khajehpour and Grierson 2003). Coaffee et al. (2009) discuss the visual impact of counter-terrorism security measures. Visible security features 'tell' the public that a place can be used safely, while potential offenders 'are 'told' that their malign intent is likely to be in vain or at least will require a significant degree of effort' (Coaffee et al. 2009). Security features can, however, also increase fear by drawing attention to the fact that security is necessary for protection (Zedner 2003; Coaffee et al. 2009; Lemanski 2004).

Gamman and Thorpe (2007) discusses trade-offs between providing bicycle parking and terrorism prevention and argue that monitored long-term parking can both reduce bicycle thefts and prevent bicycle bombs, while providing short-term bicycle parking that does not allow for bicycle bombs might be more challenging. They do, however, argue that removing bags from bikes (rather than bikes) should, in most cases, sufficiently address the risk of terrorism (Gamman and Thorpe 2007). Armitage and Monchuk (2009) explore conflicts and synergies between security and sustainability of housing. To facilitate robust and effective security which does not incur unnecessary costs, Little (2004) calls for holistic security where interactions between government officials, security professionals, program and financial staff, and emergency responders occur regularly, rather than on a project-by-project basis. Better planning before constructing buildings with protection needs would also enable us to solve many troublesome trade-offs.

Ekblom and colleagues have developed a four-level framework, the SFF, for describing a product's 'security function'. This framework was constructed with the purpose of describing both the rationale that underlies a crime-resistant design and the immediate output of the 'design-against-crime' process (Ekblom 2012). The SFF can be briefly summarized (Ekblom et al. 2012; Ekblom 2012):

- Purpose - what the designed product is for, including both security and other requirements.

- Niche - how the security function of a given product relates to other security arrangements.

- Mechanism - how the product's security function works in terms of cause and effect.

- Technicality - how the product is constructed and manufactured and how it operates.

Ekblom (2012) distinguishes between different purposes: (1) the principal purpose, which may or may not be one of security, (2) subsidiary purposes, (3) desire requirements that are beneficial to the immediate users and manufacturers, and (4) 'hygiene' or socialresponsibility requirements, referring to other societal values which the product should not interfere with.

Work within the Design against Crime Research Centre has contributed to this framework and two projects were especially relevant: The Bikeoff project, whereby parking stands and other facilities were developed to be secure against bike theft (Thorpe et al. 2012), and the Grippa Clip, which addressed preventing theft of customers' bags in bars through specially designed anchoring clips to fit on tables (Ekblom et al. 2012). Meyer and Ekblom (2012), furthermore, did a desktop test of the SFF by using it to specify design requirements of an explosion-resistant railway carriage. They concluded that the framework was clearly expressed, facilitated structured creativity, and was seemingly quite practically applicable (Meyer and Ekblom 2012).

The above studies use the SFF to spell out the design of relatively contained products. The FGC of Norway is a more complicated and multifaceted product. It will contain government functions that are essential for the 
governance of a country. The complex will also be situated in a dense city-centre area and its features will impinge on all the numerous neighbours and city-centre visitors. The FGC will therefore have some impact on many equally essential values. Hence, this study asks: Can the SFF be successfully employed in the case of the FGC of Norway? And will the framework help illuminate the 'troublesome trade-offs' when constructing a new government complex? We reformulate the three assessment criteria employed in Meyer and Ekblom (2012): 1. The terms employed in the SFF should also be easily employed in the FGC (clearly expressed); 2. The SFF should support the users of the framework in exposing additional troublesome trade-offs (fertile); and 3. It should help users to produce relevant solutions to the troublesome trade-offs (practically applicable).

The next section describes the information-collection process used in the study discussed in this paper. Section three employs the SFF in the FGC: (1) the purposes of the FGC, (2) the security niche of the FGC, (3) the mechanism behind protecting against VBIED attacks, and (4) some technicalities of implementing standoff. Section three also outlines the troublesome trade-offs between implementing standoff and achieving other purposes of the FGC. Finally, section four assesses the performance of the SFF in analysing the FGC, and section five concludes the paper.

\section{Method}

The case of the FGC of Norway is interesting because it is rare that a new government complex is planned in such a dense area of a city (see Figure 1). The government complex in Berlin is the nearest example case the authors know of, but in that case the city had lots of free space owing to the removal of the Berlin Wall ${ }^{\mathrm{a}}$. The procedural requirements of a large public-procurement exercise in Norway also make it easier to examine the motivations and the justifications behind all the choices for the FGC.

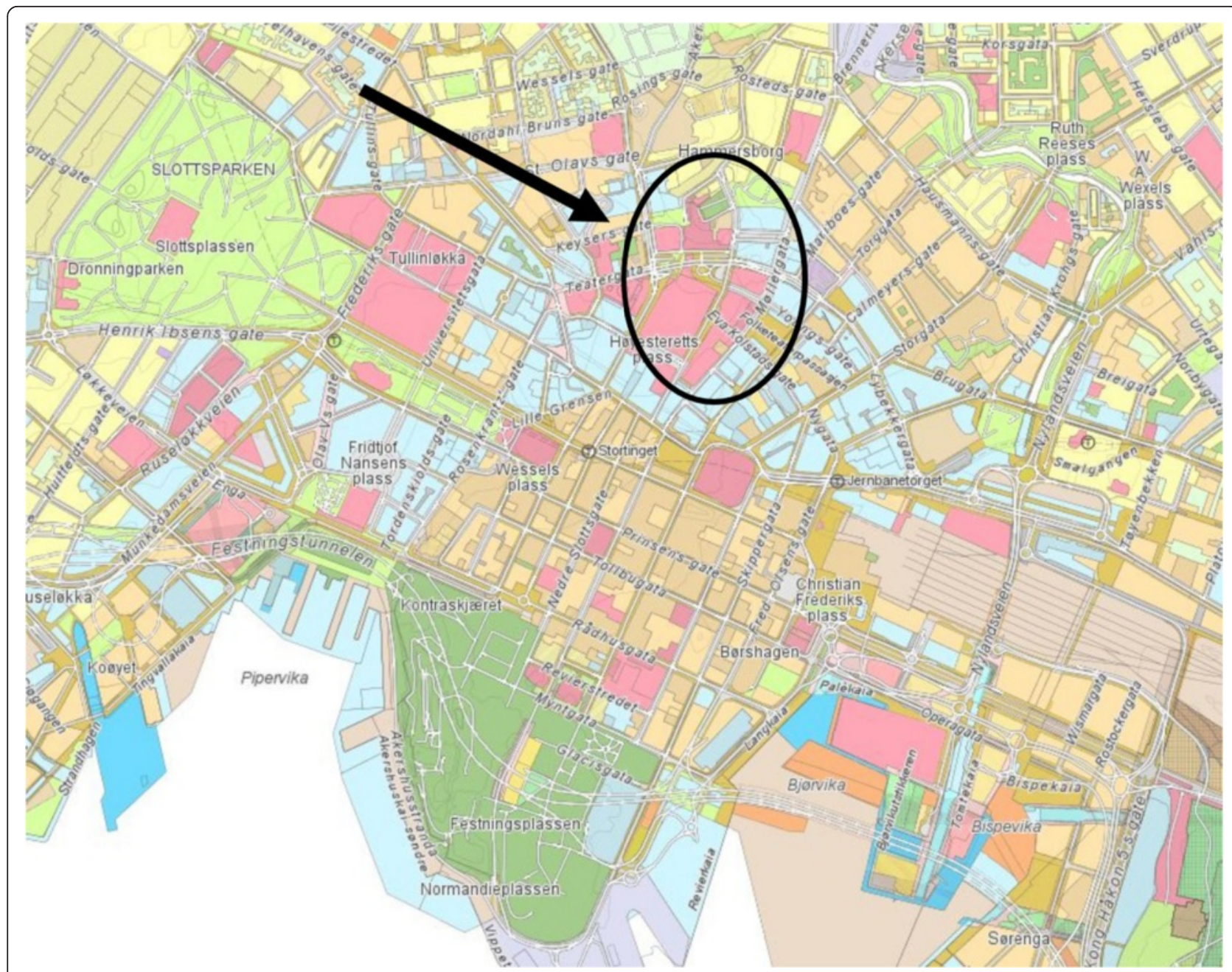

Figure 1 The city centre of Oslo. The circle encompasses the area where the government complex will be situated $^{b}$. 
The authors were involved in the quality assurance of the concept study for the FGC (Minken et al. 2009). The quality assurance was carried out autumn 2013 and winter 2014, and the quality assurance report was presented to the Ministry of Government Administration, Reform and Church Affairs February 2014. As part of this process, we interviewed relevant stakeholders on their perspectives concerning the complex. The interviews were all semi-structured (Leech 2002) and always conducted by at least two interviewers (for some interviews even three or four interviewers). The interviewers took notes and these notes were compared after the interviews. All these interviews were confidential, so we cannot refer specifically to any particular one (or produce direct quotes) when we discuss the issues raised in the interviews. We have, however, included a list in the Table 1 of all the interviews that at least one of the authors participated in (Berntsen et al. 2014).

In addition to the interviews, we conducted a document analysis of relevant policy documents, such as the mandates for the concept study and the quality assurance, the concept study, and other publicly available sources (Metier, OPAK, LPO arkitekter 2013; Ministry of Government Adminstration, Reform and Church Affairs 2012, 2013).

After finishing the quality assurance of the concept study, we collected relevant academic literature and employed the SFF on the information collected through the quality assurance process.

\section{Results}

The security function of the FGC

This section presents the results of employing the SFF in the FGC of Norway. The FGC involves a vast number of stakeholders, including everything from the city of Oslo to the small corner store in the neighbourhood, but this paper lacks space to examine all stakeholders' perspectives. The discussion below, therefore, pays particular attention to the Norwegian authorities' perspective and deals only with other stakeholders' perspectives when official government documents explicitly refer to their interests.

\section{Purpose}

According to the mandate for the concept study (Ministry of Government Adminstration, Reform and Church Affairs 2012), a new government complex must be prepared to provide a long-term solution for [functional] premises for the majority of the ministries. The mandate for the quality assurance is more specific; it says that 'the majority of the ministries' implies significantly more than half of the ministries (Ministry of Government Adminstration, Reform and Church Affairs 2013). Both mandates specify that the ministries should be located in the area for many decades to come (Ministry of Government Adminstration, Reform and Church Affairs 2012, 2013). Since the FGC will be designed to provide functional premises for the ministries, this purpose can be referred to as the primary purpose of the FGC.

Table 1 Interviews conducted as part of the quality assurance where at least one of this article's authors participated

\begin{tabular}{lll}
\hline Date & Topic(s) & Organisation \\
\hline 26.09 .13 & Site survey, security & Ministry of Government Administration, Reform and Church Affairs \\
& & Statsbygg \\
27.09 .13 & Security & Norwegian Police Security Service \\
01.10 .13 & Security & Norwegian National Security Authority \\
02.10 .13 & Security & National Police Directorate Norway \\
03.10 .13 & Security, costs & Norwegian Defence Estates Agency \\
07.10 .13 & Accessibility for emergency vehicles & Agency for Fire and Rescue Services, City of Oslo \\
08.10 .13 & Accessibility, public transport & Ruter AS (common management company for public \\
09.10 .13 & Space requirements, security & transport in Oslo and Akershus) \\
10.10 .13 & Accessibility for emergency vehicles & Norwegian Government Security and Service Organisation \\
10.10 .13 & Security & Ambulance and Paramedic Department, Oslo University Hospital \\
18.10 .13 & Implementation strategy, costs, security & Norwegian Defence Research Establishment \\
18.10 .13 & Planning process, accessibility, the urban environment & Statsbygg \\
& & Vice Mayor of Urban Development, City of Oslo \\
24.10 .13 & Special needs SMK & Agency for Planning and Building Services, City of Oslo \\
30.10 .13 & Security, emergency planning, costs & Agency for Urban Environment, City of Oslo \\
\hline & Security, emergency planning & Office of the Prime Minister \\
& & Ministry of Justice and Public Security \\
Emergency Planning Agency, City of Oslo
\end{tabular}


The mandates, furthermore, stipulate that the premises must satisfy necessary requirements for both flexibility and security. The premises must be flexible enough to handle changes in both the ministerial structure and the working methods, and must satisfy necessary security requirements (Ministry of Government Adminstration, Reform and Church Affairs 2012, 2013). These purposes (about flexibility and security) are not what the FGC is designed for, but they describe properties of the FGC that are so crucial that they can be referred to as subsidiary purposes.

Interviews with relevant stakeholders have also uncovered some other requirements for the FGC: the FGC should be 'representative'. By 'representative' they we mean that the FGC must favourably project Norway and the Norwegian government. The buildings should be well designed, on the outside and inside, and should be magnificent without being too grand to represent Norwegian identity and culture. The 'representative' requirement is a desire requirement, because it is not strictly necessary, but nevertheless is a nice-to-have feature for the Norwegian government.

Inherent in any concept study and quality assurance of large public projects are calculations of the investment cost. This cost focus shows that minimizing expenses also is a desire requirement. Minimizing running costs, such as heating, maintenance, and surveillance, is probably also a desire requirement.

The mandates also mention some requirements that refer to other societal values. These values include traffic flow and environmental requirements for the buildings (Ministry of Government Adminstration, Reform and Church Affairs 2012, 2013). According to the SFF, 'hygiene' or social-responsibility requirements should not be unnecessarily interfered with. The FGC of Norway will be situated in the middle of Oslo's city centre and will have a very large impact on the whole area. Some might therefore argue that the FGC should preferably reinforce, rather than avoid interfering with, other societal values, such as accessibility, openness and environmental considerations.

After the concept study was released in June 2013, a big debate arose regarding preservation of some of the older government buildings. The Directorate of Cultural Heritage, therefore, did their own study (with a mandate from the Ministry of Environment) of the preservation value of these government buildings. It concluded that two of the buildings the concept study recommended for demolition were of very high preservation value (The Directorate of Cultural Heritage 2013). The debate and the sudden ordering of the new study demonstrate that, even if not mentioned in the mandates, preservation also is a societal value that the FGC should not unnecessarily interfere with.
The 2014 draft budget of Oslo City Council states that Oslo City Council will be working towards providing safe and secure public spaces. The Council has therefore established a safety index based on the police's crime statistics and annual surveys of the population (Oslo City Council 2013). Safety from both deliberate and accidental harm is, accordingly, another societal value the FGC should reinforce or, at a minimum, avoid interfering with.

Vibrant Oslo (Levende Oslo) is a project whose aim is to increase the activity in the city centre (City of Oslo 2014). Activity in public space depends on the presence of some attractive characteristics, including accessibility, aesthetics and safety (Gemzøe 2006). In addition, people use public space when they either are passing through or have a destination situated in the area (e.g. street vendors, entertainment centre or public transport). Most visitors to the area, whether on business or sightseeing, will travel there because they are intending to visit the ministries. But to ensure activity outside office hours, the area will need after-hours attractions. Will a buffer zone paralyze all other activities in the area or could it help reinforce activity by offering other visitors something to do?

\section{Security niche}

The security niche characterizes how the security function relates to other security-related products, people and places (Ekblom 2012). But before describing a security niche of the $\mathrm{FGC}^{\mathrm{c}}$ a more thorough look at the risks the government complex faces is necessary.

The government complex comprises functions, employees and material values, all of which need protection from a broad range of risks. The concept study mentions intentional acts, such as crime, intelligence gathering, terrorism and sabotage, and other unwanted incidents, such as fire, water damage, and loss of electricity or power. In addition, the study formulated seven absolute security requirements that indicate some risks its authors considered important (Metier, OPAK, LPO arkitekter 2013, p. 75) [authors' translation]:

1. That there be a minimum of 20 meters from general vehicle traffic to government buildings, a distance requirement that must be increased to 40 meters for those parts of the government complex containing national functions that are either especially critical and/or under heightened threat (infrastructure).

2. That the construction of buildings be undertaken in line with specific principles.

3. That there be resistance to attacks using improvised charges whether transported or carried.

4. That there be no physical contact between government buildings (controlled area) and private 
buildings (uncontrolled area). If the distance is absent or less than 5 meters, appropriate safeguards must be implemented.

5. That the possibility of shooting be minimised by limiting the view into the buildings.

6. That there be individual safeguarded pathways for critical infrastructure and separate transport routes for trade and logistics staff.

7. That the facades be surveillable.

The first three absolute security requirements deal mainly with explosive attacks. Security requirement number 1 (standoff) has been imposed to counter a vehicleborne threat, probably primarily to counter a VBIED threat, such as the case of the Breivik bombing of the old government complex, but it could also help impede other vehicle-borne attacks (e.g. using a vehicle as a ram). Security requirement number 2 has been imposed such that the buildings should be able to withstand large explosions. Security requirement number 3 has been imposed to counter smaller explosions that might also occur inside buildings.

The next three absolute requirements deal with more diverse threats. Security requirement number 4 counters hostile intelligence and other intrusions. Security requirement number 5 counters assassinations, as well as hostile intelligence. Security requirement number 6 counters any misdeeds against critical infrastructure, whether for hostile intelligence gathering, contamination, or cutting of the infrastructure, and impedes smuggling of unwanted materials and unwanted intrusion. Security requirement number 7 supports the detection of all illegitimate behaviour.

The FGC is thus exposed to significant threats, threats that it must be protected from. The FGC will therefore be protected by separate security products and securing products. A security product's main purpose is to protect the FGC (Ekblom 2012). Examples of security products include bollards, fire alarms, and CCTV. A securing product is one that has a subsidiary (secondary) purpose (protecting the security of the government complex, that is, securing the government complex) in addition to whatever its principal purpose is (Ekblom 2012). Landscaping might be considered a securing product, for example.

Using security and securing products to protect the government complex makes for a secured complex, protected by external means. But incorporating security or securing products or incorporating deliberate security adaptations can make the government complex an inherently secure one (Ekblom 2012). For example, a blast-resistant window is a securing component with the principal purpose to admit light while protecting against the weather, and the subsidiary purpose to protect against blast effects. An example of a deliberate security adaptation is to use structural redundancy to protect the complex and its inhabitants in case of a bomb attack.

Standoff (which is the focus of the rest of the paper) is another example of a security adaptation that protects against all vehicle-borne threats.

\section{Mechanism}

The causal mechanisms describe how the design intervention works by interrupting, diverting or weakening a security threat (Ekblom 2012). The design of the FGC will contain a vast number of causal mechanisms for intervention against security threats. This study is, as mentioned previously, limited to VBIED attacks.

One way of indicating causal mechanisms in relation to offender purposes is to identify crime scripts. A crime script is a description of the procedural sequence a criminal goes through when committing a specific type of crime. By spelling out the actions (and their goals) necessary to complete the crime, the crime script can 'enhance situational crime prevention policies by drawing attention to a fuller range of possible intervention points' (Cornish 1994, p. 159-160). Meyer (2011) developed crime scripts for an offender crashing a VBIED into a railway sites. The first crime script describes an offender parking a VBIED (Meyer 2011, p. 314-315):

1. Find suitable spot for crashing vehicle into carriage without being spotted or challenged.

2. Remove any physical obstacles without being spotted or challenged.

3. Arm device and await the right moment without being spotted or challenged.

4. Crash into site while detonating the explosives.

Meyer (2013, p. 4-5) has formulated a more detailed crime script of the offender parking a VBIED:

1. Devise outline plan:

i. Establish desired outcome (scale of death/ destruction/publicity);

ii. Establish likely target locations (Clarke and Newman 2006) ${ }^{\mathrm{d}}$.

2. Perform reconnaissance without being detected: i. of suitable area(s) for leaving a vehicle-borne device (including parking restrictions, parking enforcement, normal parking activity, physical security, closed-circuit television, and any blast enhancing factors).

ii. of transport route(s) into suitable area.

iii. of escape route(s) from suitable area.

3. Decide upon the most appropriate modus operandi (probably only two main options):

i. Time delay device (long or short); 
ii. Command initiation (remote or co-terminus (co-terminus $=$ suicide $)$.

4. Gather detailed information to support modus operandi:

i. from personal contact;

ii. from printed materials (books, newspapers, etc.);

iii. from the Internet;

iv. from first principles.

5. Locate suitable base from which to launch attack:

i. one's own property;

ii. a friend's property;

iii. a rented property;

iv. a derelict/ownerless property.

6. Consider personal security:

i. Counter-surveillance;

ii. Cover story;

iii. Physical protection.

7. Obtain suitable explosive materials/precursors without being hurt or detected (probably three main options):

Either

i. purchased, or

ii. stolen, or

iii. homemade from purchased or stolen precursors.

8. Obtain information about how to assemble a device:

i. Purchase or steal necessary materials;

ii. Purchase or steal necessary tools;

iii. Assemble device.

9. Obtain vehicle and other tools for transport and containment of explosive device without being detected.

10. Transport vehicle to target without being spotted or challenged or explosives being detonated by accident.

11. Find suitable spot for the explosive(s) and (if necessary) for nearby viewing point for detonation - without being spotted or challenged.

12. Remove any physical obstacles at detonation site without being spotted or challenged.

13. Arm device and leave vehicle without being spotted or challenged.

14. Leave area or go to viewing point.

15. Detonate device if command initiated (e.g. radio or telephone controlled) without being spotted or getting injured from explosion.

Both above crime scripts highlight the need for finding a suitable site. A standoff that creates distance between an accessible spot and the target decreases the effect from the explosion upon the intended target and thus reduces the benefit of attacking. Crime participants seek, however, to overcome the defences of their adversaries (Felson 2006). Instead of just accepting the reduced benefit of attacking, the attacker might thus adapt; whether abandoning the attack entirely, attacking another target (target substitution), or choosing a different attack mode (Meyer 2013). A standoff would, for example, protect against vehicle-borne explosives, while not being able to prevent any attack with a person-borne explosive.

The technicalities section below discusses the technical requirements for such standoff.

\section{Technicalities}

Describing the technicalities is primarily a task for future planning, but already now it is possible to set some 'performance standards' for the standoff (or buffer zone) between general vehicle traffic and the FGC.

The required distance between the perimeter boundary and the FGC depends on many variables. These include the threat level, that is, how much explosive force security experts estimate that the attacker will be able to generate, the importance and the quality of the site which must be protected, the buildings' resilience to blasts, and what sort of consequences we deem acceptable in case of a VBIED attack.

In addition to the distance requirements, the perimeter boundary must be able to withstand the maximum speed a vehicle can reach at the perimeter. The maximum speed depends on the surrounding areas. How is the road system constructed? Can a vehicle use the roads to accelerate straight towards the boundary or will the road system force the vehicle to slow down? Speed reduction measures around the buffer zone, such as bumps and curved roads, can therefore reduce the maximum force the perimeter boundary must withstand.

The width between obstacles must, furthermore, not be greater than 1.26 meters (Forman et al. 2009). If some vehicles are to have access to the buffer zone, access control is necessary. Electronic keys are a relatively easy and inexpensive way to manage such access control, but unmanned gates are vulnerable to tailgating (sneaking a car in behind a legitimate user) and keys may go astray and are susceptible to hacking. For this reason, a guarded gate is probably more secure. However, such a gate must have protection that can withstand an accelerating vehicle, and turning space for vehicles denied access (a rejection line). The guards must also be protected to minimize the possibility that they will be threatened or forced to open the gate.

\section{Troublesome trade-offs}

The above section shows why the FGC of Norway needs a standoff (buffer zone) between the government complex and general vehicle traffic. This measure has, however, more consequences than intended by the measure and we refer to these consequences as externalities. This section accounts for these externalities and compares 
them with the other purposes of the FGC to uncover any 'troublesome trade-offs'.

\section{Principal purpose}

The principal purpose of the FGC is to provide longterm, functional premises for the majority of the ministries, that is, the FGC must provide necessary space for functioning ministries. The area available for building the FGC is limited in extent. The quality assurance report of the concept study demonstrated that if the FGC is to accommodate all the ministries for more than 50 years, the area must be densely developed (Berntsen et al. 2014). Using space for buffer zones leaves less space for development and makes it even more necessary to build denser and taller buildings in the remaining area, and can make the FGC a less long-term solution.

For a fully functional government complex, all legitimate users, such as employees and visitors, need reasonably easy access. Introducing a buffer zone will make it more difficult, if not impossible, for many users to access the FGC by car ${ }^{\mathrm{e}}$. Figures 2 and 3 displays two suggested government complexes where the government buildings are marked in red and dashed lines mark the streets which the concept study recommends should be closed off for general vehicle traffic. Figure 2 shows a reused version of the old government complex, while Figure 3 shows the current plans for the future government complex (Metier, OPAK, LPO arkitekter 2013). However, given the environmental policy objective to reduce vehicle traffic in the city centre, such an obstacle might be positive. If legitimate users end up choosing to travel by public transport, to walk, or to cycle, such a buffer zone will contribute to fewer carbon emissions. Such an externality might thus be called a positive externality.

Some legitimate users may have disabilities that make them dependent on motorized vehicles. To ensure that they also have access, both the outdoor areas and closeby public transport must be inclusively designed.

A fully functional government complex requires deliveries. An external commodity reception where all items are inspected before they are forwarded to the government complex in security-cleared vehicles may ensure that deliveries do not compromise the buffer zone. This solution may also be both cost effective and environmentally friendly.

\section{Subsidiary purposes Flexibility purpose}

The concept study for the FGC formulated, as mentioned, the requirement that all government buildings should be situated a minimum of 20 meters from general vehicle traffic. For those parts of the government complex containing national functions that are either especially critical and/or under a heightened threat, the required distance increases to 40 meters. A distance requirement which distinguishes between two levels of security, where the 'strict' requirement of 40 meters will be employed for only a small part of the government complex, makes for a relatively flexible government complex, where most of the ministry function can be rearranged and/or moved within the complex. In other countries, the distance requirement varies more. For example, in Berlin, the authorities distinguish between three threat levels for government buildings. Only the three buildings with threat level 1 (Bundestag, Bundeskanzleramt, and Bundesministerium des Innern) have a required distance of a minimum of 50 meters to general vehicle traffic, and no streets have been closed off to general vehicle traffic outside other government buildings (Metier, OPAK, LPO 2013). Differentiation between government buildings lets the city keep more streets open, but also makes the use of the government buildings less flexible in case of changes in the ministry structure. A possible solution to this dilemma is to install flexible barriers that close off streets only when government functions that need the protection are located close to streets with general vehicle traffic.

\section{Security purpose}

A standoff between the FGC and general vehicle traffic is a security measure aimed at vehicle-borne attacks. Such attacks are relatively rare in the Western world, but the consequences can be significant should they succeed. On a daily basis, other hazards, such as accidents and ordinary criminal incidents, can be more acute.

In case of a life-threatening incident, emergency vehicles need quick access to the area. A buffer zone might delay such quick access. Good procedures to alert the guards so they can be prepared to open the gates might decrease such delays. Some incidents may also involve blocked gates (for example caused by collapsed buildings). To ensure emergency-vehicle access in such incidents, the buffer zone must have multiple access points.

In case of fire, the fire department must have access for all their cars to all major 'fire attack paths' (often the main entrance and stairways), with a maximum distance of 50 meters. In addition, the ground must be able to withstand the load of heavy fire engines and associated supporting jacks.

The FGC will have visitors that need extra security. For such visitors, waiting for access at the external perimeter may cause heightened risk of personal attacks. A gate to admit visitors with extra security needs must therefore be constructed to prevent personal attacks.

\section{Desire requirements \\ Representativeness}

The prime minister and other ministers regularly receive visitors from home and abroad and it is important for 


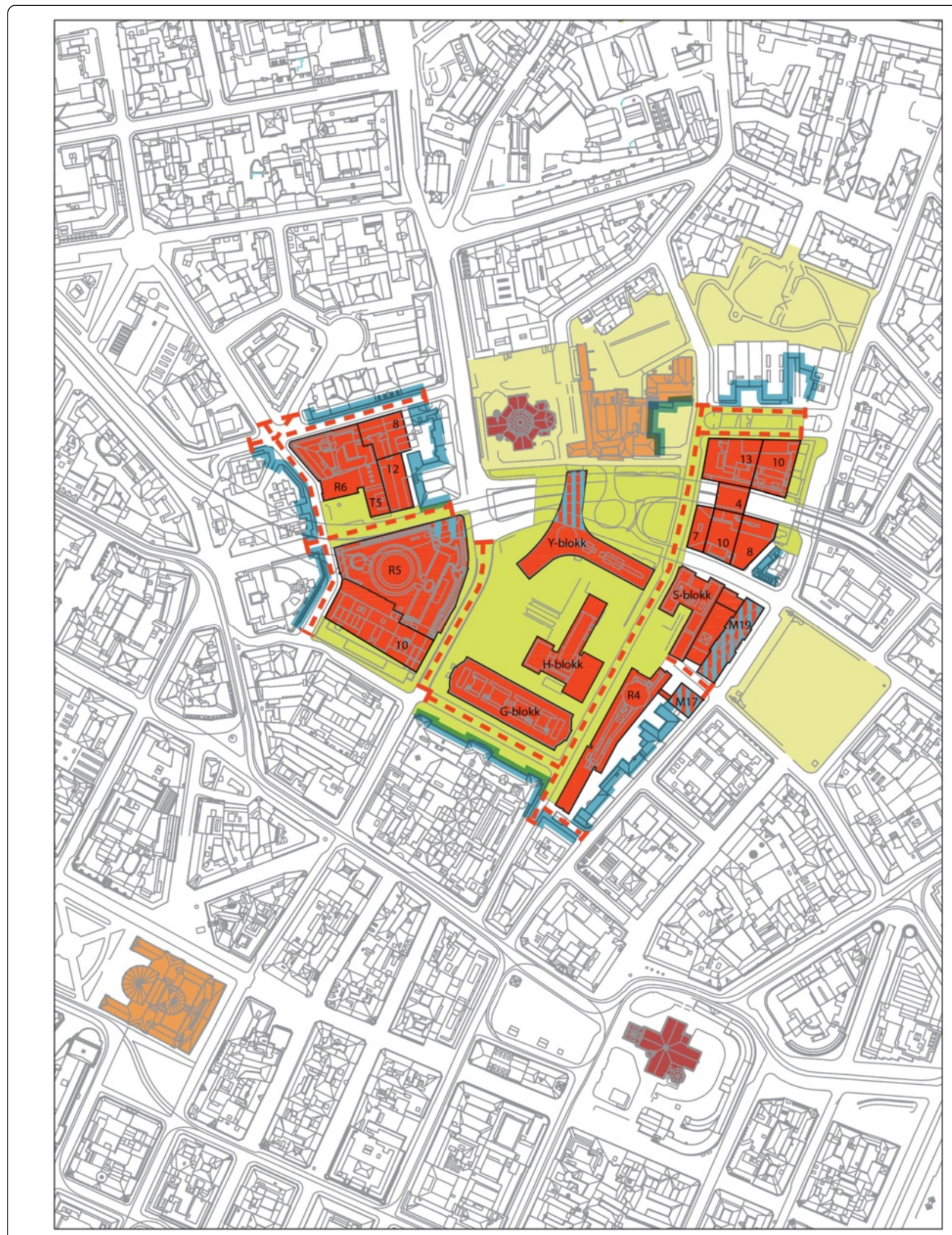

Figure 2 The reused version of the Norwegian government complex with streets closed for general vehicle traffic (dashed lines) (Metier, OPAK, LPO arkitekter 2013). 


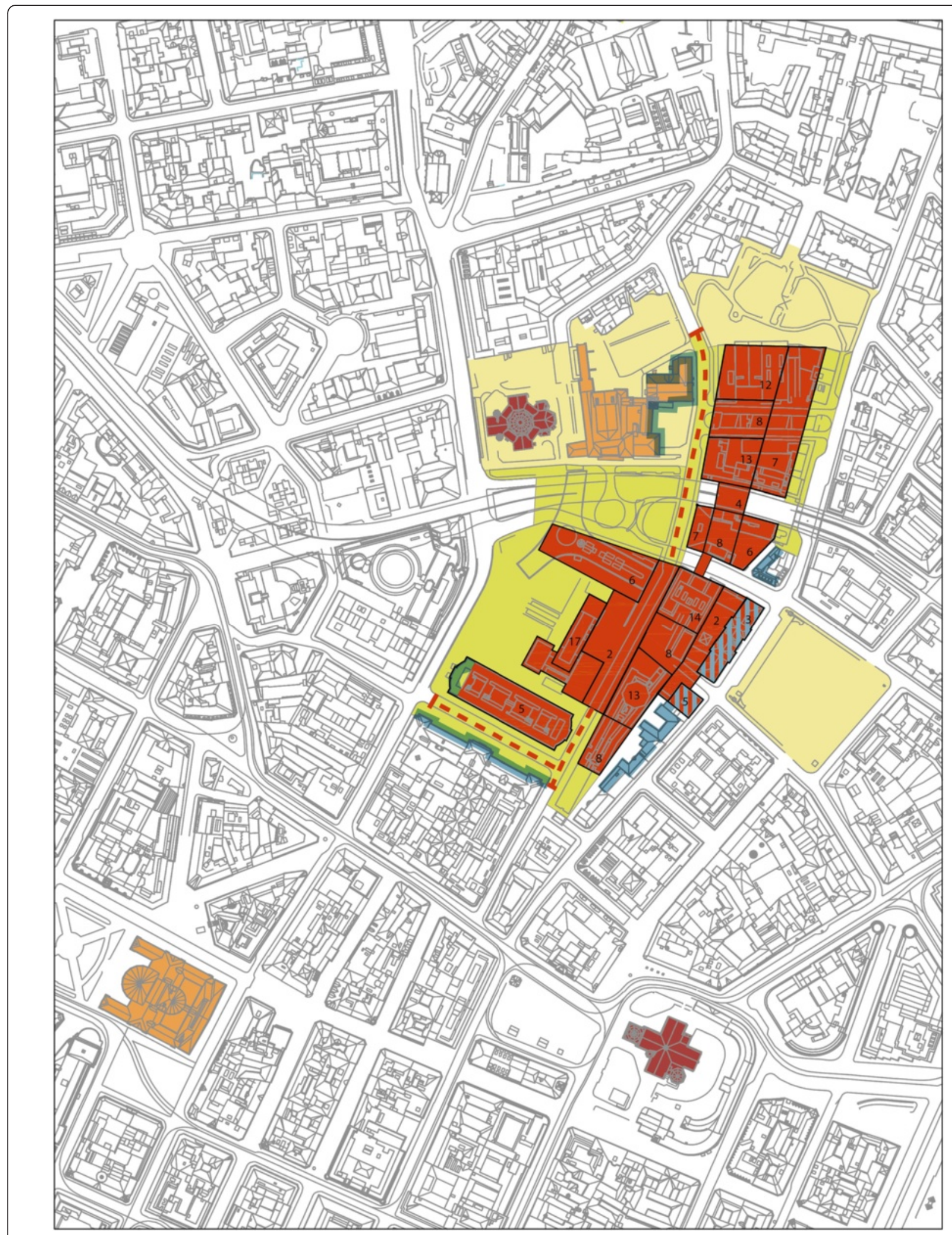

Figure 3 The planned Norwegian government complex with streets closed for general vehicle traffic (dashed lines) (Metier, OPAK, LPO arkitekter 2013). 
both the government and the rest of the state apparatus that the Norwegian government emerge with a culturally representative government complex. This requirement of representativeness applies to both inside areas and outside areas. How will the removal of almost all motorized vehicles influence the representativeness of the outside areas?

Streets with general vehicle traffic dominate outdoor areas in the city centre. However, motorized vehicles are banned in some areas, such as pedestrian streets and park areas, thus providing greater design freedom for those planning and designing the outdoor areas, and creating opportunities for spaces that are more visually pleasing. Consequently, a buffer zone that excludes motorized vehicles will probably increase the representativeness of outdoor areas.

A buffer zone around the government complex must, as mentioned, be protected by barriers along the perimeter. Such barriers can be ugly, such as blocks of concrete, or pretty, such as reinforced planters. To ensure the representativeness of the government complex, these barriers should be designed to increase the attractiveness of the outdoor areas rather than being ugly obstacles in the urban landscape.

\section{Cost}

A buffer zone will, all things being equal, increase the size of the FGC and thus increase its construction costs. However, a buffer zone will reduce other security costs related to protecting against VBIED attacks. For example, a large standoff will reduce the required structural redundancy in buildings and thus reduce investment cost. Lack of a standoff would also force security to continuously monitor all areas with vehicle access close to the FGC and thus significantly increase security-related running costs.

\section{'Hygiene' or social-responsibility requirements}

Even if social-responsibility requirements are mentioned last on the SFF's list of purposes, the location of the FGC in a densely built city-centre area, affecting a vast number of neighbours and travellers, makes social-responsibility requirements very salient. Different stakeholders, such as different governmental authorities, also disagree about which requirements are more important.

\section{Accessibility}

A buffer zone that excludes general vehicle traffic will obviously impede ordinary motorists travelling into or through the government complex. However, given the environmental policy objectives to reduce car traffic in the city centre, reduced motorized traffic can also be positive. Some vehicle-access issues are, however, more salient than others. If a buffer zone causes emergencyservice response times to neighbours of the government complex to be too long, compensatory measures must be implemented.

Commerce depends on deliveries. If a buffer zone interferes with deliveries to neighbourhood commercial businesses, alternative routes must be established. Some commodities may also be transported without using a motorized vehicle.

Public transport, both underground and surface transport, is an essential part of a vibrant city centre. Some public transport modes are underground, such as the regular railway and the Oslo Metro, while others require space on the surface and, thus, might be impeded by a buffer zone. In Oslo city centre, both tram and bus lines require surface space, and while current tram lines bypass the area designated for the FGC, conflict over a bus route which originally passed through the government complex has already arisen. Even one bus route through a buffer zone creates specific security challenges: a bus is easy to obtain on the open market and could be turned into a giant bomb disguised as a regular vehicle. In addition, public transport depends on predictable conditions, and would suffer if heightened readiness were to cause disruptions in the regular schedule.

Removing motorized vehicles frees space, providing more space for other road users, such as pedestrians and cyclists. Motorized vehicles might also limit vulnerable road users' mobility by being a 'threat' to them. Thus, by reducing accessibility for motorized vehicles, such a buffer zone, might increase accessibility for pedestrians and cyclists.

\section{Environmental considerations}

Removing vehicles will, as mentioned, have positive environmental effects by encouraging a shift to more environmentally friendly transport. In addition, the buffer zone can be planted and thus provide green spaces for the densely built city centre.

\section{Preservation}

The Ministry of Environment emphasizes that cultural heritage is an important resource that must be protected and expanded even while cities are transforming. In other words, the conservation value of older structures must be considered when redeveloping the city. A challenge with using older buildings for government purposes is that they often are less space efficient than newer purpose-built structures. Keeping old structures will therefore have to be compensated for by increasing the outdoor space needed to build the FGC (Berntsen et al. 2014).

\section{External security needs}

For common citizens either travelling through the FGC or just spending time in outside areas, other risks might 
be more salient than the risk of a vehicle-borne attack against the government complex. For example, the risk of robbery and/or rape might make citizens choose against using outside areas at night. Jane Jacobs' concept of eyes on the street claims that movement through an area will create natural surveillance (Jacobs 1961), and since criminals do not generally wish to be observed or apprehended, such surveillance can prevent crime. Intelligently designed landscape and lighting can promote natural surveillance from the interior of a building and from the exterior by neighbours and passers-by (Cozens 2002). Car occupants, cyclists, and pedestrians can function as eyes on the street, and if reduced driving through the area is compensated for by increased cycling and walking, natural surveillance need not be diminished. It is, furthermore, likely that slow road users in the open have a greater preventive effect than do passengers travelling fast inside a vehicle.

The FGC will, as mentioned, face a wide range of risks. The Government Administration Services will therefore employ CCTV surveillance in their effort to handle these different risks. This monitoring capacity can also be employed to detect crimes against citizens, such as rapes and robberies. If security personnel interrupt detected crimes and/or the information is used in subsequent investigation and prosecution, such CCTV can serve to increase the overall security of the protected area and to provide more security for general citizens using outdoor areas. Use of this measure is likely to more than compensate for any reduced security caused by excluding vehicles.

Having fewer cars in the buffer zone will initially reduce encounters between vulnerable road users (pedestrians and cyclists) and motorized vehicles. Fewer such encounters will also, other things being equal, lead to fewer road accidents between vehicles and pedestrians. If vulnerable road users are unwary of motorized vehicles (risk compensation), the advantageous effect (a reduction in road accidents) of fewer cars is reduced. Such risk compensation will, however, probably not entirely eliminate the beneficial effect of decreasing the number of motorized vehicles. An increase of vulnerable road users in the area, however, can increase conflicts between cyclists and pedestrians, which might in turn cause more accidents between such road users. Fortunately, traffic accidents involving only such users usually result in injuries of a less serious nature; therefore, an increase in such accidents will unlikely be large enough to remove the positive impact on road safety of reducing the number of cars.

Winter maintenance should not be neglected just because motorized traffic is reduced. For example, if footpaths are slippery, accidents might rise given possibly increased pedestrian and cycle traffic due to reduced motorized traffic. For the sake of remaining users, winter maintenance should therefore not be neglected in the buffer zone.

\section{Vibrant city centre}

To ensure that the area around the FGC is vibrant and that people choose to use the area, it is important that both regular users and visitors perceive the area as attractive, regardless of gender, age, income, or education. Offering a variety of entertainment motivates people to spend time in public spaces. Removing general vehicle traffic might banish activities that rely on frequent deliveries. However, the buffer zone can also be used to provide an attractive recreation area, such as a park with a skate ramp. In addition, buildings on the FGC's fringe, such as the old Oslo Public Library, can be redeveloped as attractions for the greater population. A challenge here would be to introduce attractions that do not sacrifice other security requirements, such as protection from intelligence gathering, for example, hostile reconnaissance using binoculars from high buildings.

\section{Summary}

Table 2 summarizes both the challenges and the opportunities connected with introducing a buffer zone with reduced accessibility for motorized vehicles.

\section{Discussion}

This paper has extended the use of the SFF from relatively straightforward products, such as the Grippa Clip and a railway carriage, to the many-faceted FGC. In Meyer and Ekblom (2012), the authors assessed the framework by discussing whether it (1) was clearly expressed, (2) facilitated creativity, and (3) was practically applicable. After employing the framework in the FGC of Norway, this paper's authors would like to comment on those three criteria.

Our experience is that the SFF terms were relatively easy to employ when describing the FGC's security function. It was not evident that a framework developed for straightforward products would also work for such a many-faceted development, but we had no problems when describing the security function. This study has thus reinforced the claim that the SFF is clearly expressed.

Meyer and Ekblom (2012) concluded, after a short discussion, that the SFF facilitated structured creativity. In the current case, the authors identified many of the concrete challenges and opportunities before they employed the SFF, partly since the framework was employed so late in the investigation. However, the framework forced the authors to rethink, and to connect the purposes of the FGC to the challenges and opportunities, and thereby made the underlying conflicting principles more evident. The SFF is therefore fertile in the sense that it structures the argument and clarifies the contact points 
Table 2 Outline of challenges and opportunities/solutions

\begin{tabular}{|c|c|c|}
\hline Requirements & Challenges & Opportunities/solutions \\
\hline \multicolumn{3}{|l|}{ Primary purpose } \\
\hline \multirow[t]{2}{*}{ Space } & Less space for buildings & Building denser \\
\hline & & Constructing taller buildings \\
\hline \multirow[t]{2}{*}{ Functional } & Deliveries & External commodity reception \\
\hline & Reduced accessibility for disabled people & Constructing areas that improve inclusive access \\
\hline \multicolumn{3}{|l|}{ Subsidiary purposes } \\
\hline Flexibility & Variable distance requirements & Flexible barriers \\
\hline \multirow[t]{2}{*}{ Internal security } & Emergency vehicle access & Multiple access points \\
\hline & Secure access for important visitors & Protected access points \\
\hline \multicolumn{3}{|l|}{ Desire requirements } \\
\hline Representative & Ugly barriers & Constructing barriers that increase the attractiveness of outdoor areas \\
\hline \multicolumn{3}{|c|}{ Social-responsibility requirements } \\
\hline \multirow[t]{3}{*}{ Accessibility } & General vehicle access & Better pedestrian and bicycle access \\
\hline & Deliveries & Alternative routes and/or transport by non-motorized vehicles \\
\hline & Public surface transport & Increase underground transport \\
\hline \multirow[t]{2}{*}{ Environmental concerns } & & More environmentally friendly transport \\
\hline & & Green outdoor areas \\
\hline Preservation & Less space-efficient use of land & \\
\hline \multirow[t]{2}{*}{ External security } & Fewer eyes on the street & Employing formal surveillance to make other citizens feel safer \\
\hline & & Better road safety for the remaining road users \\
\hline Vibrant city centre & Deliveries for attractions & Using the buffer zone to create attractions \\
\hline
\end{tabular}

between the different purposes, as well as offering a systematic approach to gather and systemize the relevant information.

The FGC is a project that by all appearances will be realised, and the ideas formulated in this paper could therefore be further tested during the development and the building of the FGC. A brief look at Table 2 also shows that all of the suggested solutions are possible to realise and could be implemented, given a positive political climate. However, one of the main reasons for the solutions' feasibility is that they seek to implement stakeholders' expressed wishes as revealed during the authors' comprehensive information collection amongst the stakeholders. The SFF can therefore aid in clear thinking and structured creativity, but it cannot compensate for comprehensive information collection among different stakeholders to ascertain their various perspectives by way of developing solutions that meet their requirements as much as possible.

\section{Conclusion}

The purpose of this paper is twofold: First, it explores various trade-offs between standoff and other values, and, when appropriate, proposes possible solutions to such dilemmas. Second, it asks whether employing the
SFF in the FGC of Norway will help illuminate these 'troublesome trade-offs'.

The analysis has demonstrated that standoff creates challenges for other purposes of the FGC, such as functional office spaces for all employees, but many of these challenges can be solved by planning intelligently, such as creating an external commodity reception. Standoff also creates opportunities for reinforcing social-responsibility requirements, such as accessibility for pedestrians and environmental considerations. The current literature has mostly focused on negative externalities of security, while this paper demonstrates that security measures can have both negative and positive externalities and that planning might alleviate some of the negative ones. The results, furthermore, support Little's (2004) notion about thinking holistically about protection to create robust and effective security, and show that the academic community can assist in such holistic thinking.

The discussion showed that the SFF is expressed in terms that also can be employed in the multifaceted FGC of Norway. The framework, furthermore, forced the authors to rethink and connect the purposes of the FGC to the challenges and opportunities and made the underlying conflicting principles more evident. The solutions proposed through this process were also practically 
applicable, but one of the main reasons for the solutions' feasibility was probably the comprehensive information collection prior to employing the framework.

This paper focuses on one measure, standoff, and explores the trade-offs between employing standoff and other purposes/values. All the dilemmas mentioned are therefore two-dimensional. Such dilemmas might, however, have even more than two dimensions. For example, Berntsen et al. (2014) have shown that some trade-offs have three dimensions, such as, for the FGC of Norway, the trade-off between enough office space, standoff, and preservation. Such trade-offs should be explored further, including the three-dimensional trade-off between functional office space, environmental requirements and security measures.

Another direction for future research would be to apply the SFF to protecting even more complex 'products'. Could we extend this framework to protecting other areas, such as a park, a neighbourhood, or even a city centre?

\section{Endnotes}

${ }^{\mathrm{a}}$ Another relevant case is Oklahoma City, the capital of the U.S. state Oklahoma.

${ }^{\mathrm{b}}$ The map is owned by the City of Oslo, Agency for Planning and Building Services, and has been downloaded from http://www.planinnsyn.oslo.no/.

${ }^{\mathrm{c}}$ In this discussion the FGC is treated as a unit situated in the habitat of the wider environment of Oslo City and occupies particular security niches. One could also treat the FGC as a habitat within which smaller-scale entities, for example, specific buildings, have particular security functions and occupy niches within the complex.

${ }^{\mathrm{d}}$ EVIL DONE summarizes the main properties of the targets that terrorists choose: Exposed, Vital, Iconic, Legitimate, Destructible, Occupied, Near and Easy (Clarke and Newman, 2006).

${ }^{\mathrm{e}} \mathrm{Such}$ standoff arrangements can be (and have been) compromised if important persons expect to be taken right up to the door in their vehicles and the managers of the complex fail to resist their demands.

\section{Competing interests}

Part of this study has been funded by the Norwegian Ministry of Local Government and Modernisation.

\section{Authors' contributions}

Sunniva Meyer participated in the acquisition of data, employed the Security Function Framework on the case and drafted the manuscript. Sissel $\mathrm{H}$. Jore and Kjell W. Johansen participated in the acquisition of data and helped draft the manuscript. All authors read and approved the final manuscript.

\section{Acknowledgment}

We have received valuable comments and advice from Paul Ekblom. We would also like to thank Fran Azevedo for excellent copy editing services.

\section{Author details}

${ }^{1}$ Department of Safety, Security and the Environment, Institute of Transport Economics, Gaustadalleen 21, NO-0349 Oslo, Norway. ${ }^{2}$ SEROS - Centre for Risk Management and Societal Safety, University of Stavanger, N-4036
Stavanger, Norway. ${ }^{3}$ Department of Economics and Logisticst, Institute of Transport Economics, Gaustadalleen 21, NO-0349 Oslo, Norway.

Received: 3 September 2014 Accepted: 13 March 2015

Published online: 18 April 2015

\section{References}

Armitage R, Monchuk L (2009). Reconciling Security with Sustainability: The Challenge for Eco-Homes. Built Environment, 35(3):308-327.

Berntsen S, Sunde T, Rosseland KM, Johansen KW, Meyer SF, Jore SH, Aven T, Bratseth I, Finsveen J, Lolleng J, Steenberg G (2014) Fremtidig regjeringskvartal - Kvalitetssikring av beslutningsunderlag for konseptvalg (KS1). Dovre Group and TOI, Oslo

City of Oslo (2014) Økt byliv i Oslo sentrum. Oslo municipality. http://www. prosjekt-levende.oslo.kommune.no/article275243-20413.html. Accessed 2 May 2014

Clarke RV, Newman GR (2006) Outsmarting the Terrorists. Praeger Security International, Westport

Coaffee J, O'Hare P, Hawkesworth M (2009) The visibility of (in)security: the aesthetics of planning urban defences against terrorism. Secur Dialogue 40(4-5):489-511, doi:10.1177/0967010609343299

Cormie D, Mays G, Smith P (2009) Blast Effects on Buildings, 2nd edn. Thomas Telford Publishing, London

Cornish DB (1994) The Procedural Analysis of Offending and its Relevance for Situational Prevention. In: Clarke RV (ed) Crime Prevention Studies. Criminal Justice Press, New York, pp 151-196

Cozens PM (2002) Sustainable Urban Development and Crime Prevention Through Environmental Design for the British City. Towards an Effective Urban Environmentalism for the 21st Century. Cities 19 (2):129-137. http://dx. doi.org/10.1016/S0264-2751(02)00008-2

Ekblom P (2005) Designing Products against Crime. In: Tilley N (ed) Handbook of Crime Prevention and Community Safety. Willan, Cullompton, pp 203-244

Ekblom P (2012) The Security Function Framework. In: Ekblom P (ed) Design Against Crime: Crime Proofing Everyday Product, vol 27. Lynne Reiner, Boulder, Col, pp 9-36

Ekblom P, Bowers K, Gamman L, Sidebottom A, Thomas C, Thorpe A, Willcocks M (2012) Reducing Handbag Theft. In: Ekblom P (ed) Design Against Crime: Crime Proofing Everyday Objects, vol 27. Crime Prevention Studies. Lynne Rienner, Boulder, Col, pp 167-200

Ettouney M, Smilowitz R, Rittenhouse T (1996) Blast resistant design of commercial buildings. Pract Period Struct Des Construct 1(1):31-39, doi:10.1061/(ASCE)1084-0680(1996)1:1(31)

Felson M (2006) Crime and Nature. Sage publications, Thousand Oaks

Forman P, Evans D, Heward G (2009) Chapter 11 - Vehicle-Borne Threats and the Principles of Hostile Vehicle Mitigation. In: Cormie D, Mays G, Smith P (eds) Blast Effects on Buildings. Thomas Telford Limited, London

Gamman L, Thorpe A (2007) Liberty Versus Safety: A Design Review. University of Arts, London

Gebbeken N, Döge T, Larcher M (2012) Safety and Security of Urban Areas through Innovative Architectural and Structural Concepts. In: Aschenbruck N, Martini P, Meier M, Tölle J (eds) Future Security, vol 318. Communications in Computer and Information Science. Springer Berlin Heidelberg:153-164. doi:10.1007/978-3-642-33161-9_22

Gemzøe L (2006) Quality for People, a set of Quality Criteria for the Design of Pedestrian Places and Networks: With People in Mind. Paper presented at the "Next Steps", the 7th International Conference on Walking and Livable Communities, Melbourne, Australia

Jacobs J (1961) The Death and Life of Great American Cities. Vintage Books, New York

Khajehpour S, Grierson DE (2003) Profitability versus safety of high-rise office buildings. Struct Multidisc Optim 25(4):279-293, doi:10.1007/s00158-003-0297-4

Leech BL (2002) Asking questions: techniques for semistructured interviews. Pol Sci Pol 35(04):665-668, doi:10.1017/S1049096502001129

Lemanski C (2004) A new apartheid? the spatial implications of fear of crime in cape town, south africa. Environ Urbanization 16(2):101-112, doi:10.1177/095624780401600201

Little R (2004) Holistic Strategy for Urban Security. Journal of Infrastructure Systems 10 (2):52-59. doi:10.1061/(ASCE)1076-0342(2004)10:2(52)

Loukaitou-Sideris A (2006) Is it safe to walk?1 neighborhood safety and security considerations and their effects on walking. J Plann Lit 20(3):219-232, doi:10.1177/0885412205282770 
Metier, OPAK, LPO (2013) RKV KVU B07 Referansestudier. Metier, Oslo Metier, OPAK, LPO arkitekter (2013) Konseptvalgutredning for Fremtidig Regjeringskvartal. Metier, Oslo

Meyer S (2011) Reducing harm from explosive attacks against railways. Secur J 25(4):309-325

Meyer S (2013) Impeding lone-wolf attacks: lessons derived from the 2011 Norway attacks. Crime Sci 2(1):7

Meyer S, Ekblom P (2012) Specifying the explosion-resistant railway carriage-a 'bench' test of the security function framework. J Transport Saf Secur 5:69-85, doi:10.1007/s12198-011-0082-3

Ministry of Government Adminstration, Reform and Church Affairs (2012) Mandate for Concept Study of Future Government Building Complex. Ministry of Government Administration, Reform and Church Affairs, Oslo

Ministry of Government Adminstration, Reform and Church Affairs (2013) Mandate for External Quality Assurance of the Concept Study for Future Government Complex. Ministry of Government Administration, Reform and Church Affairs, Oslo

Ministry of Local Government and Modernisation (2013) Rebuilding the government building complex. Department for Central Government Buildings, Security and Administrative Services http://www.regjeringen.no/ en/dep/kmd/subjects/Housing-and-building-policy/the-government-buildingcomplex/rebuilding-the-government-building-compl.html?id=712726. Accessed 7 March 2014

Minken H, Larsen Ol, Braute JH, Berntsen S, Sunde T (2009) Konseptvalgutredninger og Samfunnsøkonomiske Analyser. Transportøkonomisk institutt, Oslo

Oslo City Council (2013) Byrådets Forslag til Budsjett 2014 og Økonomiplan 2014-2017. Oslo City Council, Oslo

Sætnan AR, Lomell HM, Wiecek C (2002) Controlling CCTV in public spaces: is privacy the (only) issue? reflections on Norwegian and Danish observations. Surveill Soc 2:2/3

The Directorate of Cultural Heritage (2013) The government complex. The Directorate of Cultural Heritage's study on preservation value and new uses. The Directorate of Cultural Heritage, Oslo

The Public Prosecutors (2012) Indictment. Oslo Public Prosecutors, Oslo

Thorpe A, Johnson SD, Sidebottom A (2012) Designing Against Bicycle Theft. In: Ekblom P (ed) Design Against Crime : Crime Proofing Everyday Products, vol 27. Crime Prevention Studies, 27th edn. Lynne Rienner Publishers, Boulder, Co, pp 107-130

Zedner L (2003) Too much security? International Journal of the Sociology of Law 31 (3):155-184. http://dx.doi.org/10.1016/j.ijsl.2003.09.002

\section{Submit your manuscript to a SpringerOpen ${ }^{\circ}$ journal and benefit from:}

- Convenient online submission

- Rigorous peer review

- Immediate publication on acceptance

- Open access: articles freely available online

- High visibility within the field

- Retaining the copyright to your article

Submit your next manuscript at $>$ springeropen.com 